\title{
Investigation of Listeria monocytogenes in workers, equipment and environments at Kaymak processing plants
}

\author{
Recep KARA ${ }^{1 *}$ (D), Savaş ASLAN² (i)
}

\begin{abstract}
Listeria monocytogenes is a nutrient-borne pathogen spread to processed products such as vegetables, fruits and dairy products. Especially in the dairy industry, the presence of L. monocytogenes poses a major problem in milk, dairy products and dairy plants. Infection caused by this bacterium is a serious threat to individuals such as immunosuppressed patients, newborns, the elderly and pregnant women. In this study, the presence of L. monocytogenes in Afyonkarahisar/Turkey in the samples taken from plants that produce three different kaymak types was investigated. For this purpose, a total of 87 samples taken from the kaymak production plant, the surfaces of the equipment in this plant and the employees were examined according to the ISO 11290-1 protocol. According to the results of our study, L. monocytogenes was detected in $8.33 \%$ of the 36 samples taken from the processing plant and $16.66 \%$ of the total of 24 pieces of equipment in the processing plant. L. monocytogenes was not detected in the workers' hands, aprons or boots at all three plants. When the results obtained are interpreted, it is understood that this may pose a significant risk to public health if the necessary precautions are not taken in production of cream.
\end{abstract}

Keywords: Kaymak; Listeria monocytogenes; processing plant; food safety.

Practical Application: Kaymak is one of the most important milk products. It is necessary to provide hygienic conditions necessary to minimize the contamination of Listeria monocytogenes in Kaymak production.

\section{Introduction}

Listeriosis is a severe food-borne disease, often caused by consuming food contaminated with Listeria monocytogenes (Sarfraz et al., 2017). A wide range of foods, especially dairy products and processed foods, may support development of Listeria spp. Therefore Listeria outbreaks are associated with milk, cheese, vegetable salads and meat products (Gohar et al., 2017; Gérard et al., 2018). It is also reported that Listeria spp. is commonly found in milk and at farms and processing plants (Sarfraz et al., 2017). L. monocytogenes and L. ivanovii are two species that cause disease in humans and animals (Konosonoka et al., 2012). L. monocytogenes is a food-borne pathogenic bacterium that is commonly found in the environment and potentially fatal (Fox et al., 2009). L. monocytogenes, known as a psychrophilic bacterium, is a very important microorganism in foods (Sarfraz et al., 2017).

According to the Turkish Food Codex Regulation, Kaymak is defined as cream which is formed and shaped by a special method without adding any substance in which there is at least $60 \%$ milkfat (Turkey, 2003). Kaymak must not be dirty, rancid, moldy or bitter, and microbiologically, pathogenic microorganisms and their toxins must be absent (Turkey, 2011). Because kaymak is a fat-rich dairy product, it can easily deteriorate due to failure to comply with adequate hygiene and sanitation rules, packaging and storage conditions (Tomar \& Akarca, 2018).
The aim of this study was to investigate the presence of L. monocytogenes in the production environment and the equipment used at the three Kaymak processing plants.

\section{Materials and methods}

\subsection{Sampling}

The study involved an examination of samples from three different private kaymak (Afyon Kaymak) processing facilities (A, B and C) in Turkey's Afyonkarahisar province.

The samples were collected from the kaymak production plants (floor, wall, cold chamber floor, cold chamber wall, cold storage floor and cold storage wall; the total number of samples: 36 ), equipment (milk pasteurization tank, cream pasteurization tank, transport shelf, kaymak pot and knife; the total number of samples: 24) and workers (hands, aprons and boot; total number of samples: 27). As a result, the study was conducted on a total of 87 samples consisting of 36 environmental samples, 24 equipment samples and 27 worker samples from three kaymak production plants. In this study, the wet-dry double swab technique was used to collect samples from the environment, equipment and workers' surfaces from $100 \mathrm{~cm}^{2}$ sampling areas.

The collected swabs were transferred to pre-numbered tubes containing $10 \mathrm{~mL}$ Half Fraser Medium (Oxoid, SR142). All swabs were immediately transported to the laboratory in cooler boxes containing ice packs. 


\subsection{Detection of Listeria monocytogenes}

L. monocytogenes was detected according to the ISO 11290-1 (International Standart Organisation, 1996) protocol. The swabs were placed in $10 \mathrm{~mL}$ Half Fraser broth (Oxoid SR142) and incubated at $30^{\circ} \mathrm{C}$ for 24 hours. After incubation, $1 \mathrm{~mL}$ of culture was inoculated into $10 \mathrm{ml}$ of Fraser broth (Oxoid SR143) and incubated at $30{ }^{\circ} \mathrm{C}$ for 24 hours. A loop culture was incubated on Oxford Agar (Oxoid CM 856) and PALCAM Agar (Oxoid, $\mathrm{CM} 0877$ ) at $30^{\circ} \mathrm{C}$ for 48 hours. Biochemical characterization of the colonies was determined using a Microbact ${ }^{\mathrm{TM}} \mathrm{TM} 12 \mathrm{~L}$ Listeria identification system 1 (Oxoid, MB1128). Isolated L. monocytogenes was confirmed with VITEC-2 Compact with a Gram-positive identification cart.

\section{Result and discussion}

The results of this study are summarized in Table 1. L. monocytogenes was determined as $8.33 \%$ at kaymak processing plants A (cold chamber floor) and B (wall and cold chamber floor). L. monocytogenes was detected in $16.66 \%$ of all equipment (cream pasteurization tank and kaymak pot) at plant A and B. L. monocytogenes was not detected in any of the 27 samples taken from the workers' hands, aprons or boots at plants A, B and C. L. monocytogenes was not detected in anywhere at plant $\mathrm{C}$.

L. monocytogenes is a serious foodborne pathogen that may be found in raw milk and milk products. Moreover, meningitis, septicemia and very serious clinical symptoms such as miscarriage may cause Listeriosis (Akrami-Mohajeri et al., 2018; Stahl et al., 1996; Kasalica et al., 2011). Listeriosis is an infectious disease of humans and animals, and $99 \%$ of cases are caused by consumption of food contaminated by L. monocytogenes (Farber \& Peterkin, 1991; Todar, 2009). Therefore, especially contamination of milk and dairy products by this pathogen is considered as a great danger to public health (Murru et al., 2018; Akrami-Mohajeri et al., 2018; Stahl et al., 1996; Kasalica et al., 2011).
During production of food products (contamination, cutting and packaging) and in the production environment, determining the presence of $L$. monocytogenes will help avoid possible failure to implement hygienic measures. In this study, the prevalence of L. monocytogenes was investigated in samples taken from three kaymak processing plants. L. monocytogenes was detected in the processing plants $(3 / 36=8.33 \%)$ and equipment $(4 / 24=16.66 \%)$.

In the related study, Akrami-Mohajeri et al. (2018) detected Listeria spp. by $11 \%$ in 540 milk and dairy products in Iran (raw milk, cheese, butter, cream, etc.). $4 \%$ of the isolates were identified as L. monocytogenes. In terms of prevalence, the results of Akrami-Mohajeri et al. (2018) were consistent with our results. However, unlike our study, L. monocytogenes related to a single product was screened. In the study by Amajoud et al. (2018), L. monocytogenes was found in $0.74 \%$ of 404 dairy products (raw milk and whey milk) in Morocco. In comparison to our results, this ratio was found to be very low. Mary and Shrinithivihahshini (2017) isolated L. monocytogenes in 219 (52.7\%) of 415 milk and milk product samples in India. It was stated as quite a high rate that can occur through poor quality milk and additives (Mary \& Shrinithivihahshini, 2017). Similarly, Muthulakshmi et al. (2018), in their study in India, found that milk and dairy products were positive for L. monocytogenes at a rate of $11.42 \%$. Owusu-Kwarteng et al. (2018) found the prevalence of $L$. monocytogenes as 5.5\% in 254 milk samples collected from dairy farms and market vendors in Ghana. Navratilova et al. (2004) reported the presence of $L$. monocytogenes in 31 (5.0\%) of 619 raw milk samples examined in the Czech Republic between 2000 and 2002. Chavez-Martinez et al. (2019) reported L. monocytogenes in two cheese samples (cheddar and Ranchero) in Mexico.

In similar studies conducted in Turkey, Şanlibaba et al. (2018) found the presence of L. monocytogenes in $4.5 \%$ of 110 milk and dairy products they collected from markets and shops in Ankara. Aksoy et al. (2018) found that the rate of L. monocytogenes as 5\% in raw milk and traditional products in Kars. Moreover, Listeria

Table 1. Distribution and prevalence of Listeria monocytogenes at Kaymak processing plants, in production environments, equipment and workers.

\begin{tabular}{|c|c|c|c|c|c|c|}
\hline Sample type & $\mathrm{N}$ & $\mathrm{n}$ & $\%$ & A & B & $\mathrm{C}$ \\
\hline Floor & 6 & - & - & - & - & - \\
\hline Wall & 6 & 1 & 16.66 & - & 1 & - \\
\hline Cold Chamber Floor & 6 & 2 & 33.33 & 1 & 1 & - \\
\hline Cold Chamber Wall & 6 & - & - & - & - & - \\
\hline Cold Storage Floor & 6 & - & - & - & - & - \\
\hline Cold Storage Wall & 6 & - & - & - & - & - \\
\hline Total Processing Plant & 36 & 3 & 8.33 & 1 & 2 & - \\
\hline Milk Pasteurization Tank & 3 & - & - & - & - & - \\
\hline Cream Pasteurization Tank & 3 & 1 & 33.33 & 1 & - & - \\
\hline Transport Shelf & 3 & - & - & - & - & - \\
\hline Kaymak Pot & 9 & 3 & 33.33 & 2 & 1 & - \\
\hline Knife & 6 & - & - & - & - & - \\
\hline Total Equipment & 24 & 4 & 16.66 & 3 & 1 & - \\
\hline Hands & 9 & - & - & - & - & - \\
\hline Apron & 9 & - & - & - & - & - \\
\hline Boot & 9 & - & - & - & - & - \\
\hline Total Workers & 27 & - & - & - & - & - \\
\hline Total & 87 & 7 & 8.05 & 4 & 3 & - \\
\hline
\end{tabular}

N: total number of samples; n: number of positive samples; A,B,C: Different Processing plant -: Not detected. 
spp. was detected as $0.5-3 \%$ on the floor, walls, cold storage corridors and cold storage walls at five dairy plants (Tomar \& Akarca, 2019). In comparison to the results of our study, these rates seem low.

Similar to our study, Leong et al. (2014) aimed to investigate the contamination of food processing plants in Ireland. L. monocytogenes was detected in $4.6 \%$ of the samples taken from food and environmental sources (Leong et al., 2014). In the European dairy processing plant survey, the L. monocytogenes prevalence values of $7.22 \%$ and $26 \%$ were reported in Greece and Austria, respectively (Muhterem-Uyar et al., 2015). The prevalence of $L$. monocytogenes has been reported in studies conducted at cheese processing plants ranging from 33.3\% (Ibba et al., 2013) to 50\% (De Cesare et al., 2007). The differences observed in different studies may be due to milk used as raw material, processing plants, personnel, equipment used in production and storage conditions.

\section{Conclusion}

In this study, possible contamination points and frequencies of L. monocytogenes were determined at the production stages of Kaymak which is a dairy product that is produced intensively and presented to public consumption. In this study, L. monocytogenes was identified at different points during the Kaymak production process, and it may pose a potential risk to public health. Besides, it is recommended to take the necessary measures for reliable production and presentation of cream, and inform the producers and apply effective food safety control systems.

\section{Acknowledgements}

This study has been presented as an abstract paper at the $1^{\text {st }}$ International Congress on Advances in Veterinary Sciences \& Techniques Congress (ICAVST).

\section{References}

Akrami-Mohajeri, F., Derakhshan, Z., Ferrante, M., Hamidiyan, N., Soleymani, M., Conti, G. O., \& Tafti, R. D. (2018). The prevalence and antimicrobial resistance of Listeria spp in raw milk and traditional dairy products delivered in Yazd, Iran. Food and Chemical Toxicology, 114, 141-144. http://dx.doi.org/10.1016/j.fct.2018.02.006. PMid:29448094.

Aksoy, A., Sezer, Ç., Vatansever, L., \& Gülbaz, G. (2018). Presence and antibiotic resistance of Listeria monocytogenes in Raw Milk and Dairy Products. Kafkas Üniversitesi Veteriner Fakültesi Dergisi, 24(3), 415-421.

Amajoud, N., Leclercq, A., Soriano, J. M., Bracq-Dieye, H., El Maadoudi, M., Senhaji, N. S., Kounnoun, A., Moura, A., Lecuit, M., \& Abrini, J. (2018). Prevalence of Listeria spp. and characterization of Listeria monocytogenes isolated from food products in Tetouan, Morocco. Food Control, 84, 436-441. http://dx.doi.org/10.1016/j. foodcont.2017.08.023.

Chavez-Martinez, A., Paredes-Montoya, P., Renteria-Monterrubio, A. L., Corral-Luna, A., Lechuga-Valles, R., Dominguez-Viveros, J., Sánchez-Vega, R., \& Santellano-Estrada, E. (2019). Microbial quality and prevalence of foodborne pathogens of cheeses commercialized at different retail points in Mexico. Food Science and Technology (Campinas), 39(Suppl. 2), 703-710. http://dx.doi.org/10.1590/fst.30618.
De Cesare, A., Manfreda, G., Macrì, M., \& Cantoni, C. (2007). Application of automated ribotyping to support the evaluation of Listeria monocytogenes sources in a Taleggio cheese producing plant. Journal of Food Protection, 70(5), 1116-1121. http://dx.doi. org/10.4315/0362-028X-70.5.1116. PMid:17536669.

Farber, J. M., \& Peterkin, P. I. (1991). Listeria monocytogenes, a foodborne pathogen. Microbiological Reviews, 55(3), 476-511. http:// dx.doi.org/10.1128/MMBR.55.3.476-511.1991. PMid:1943998.

Fox, E., O’Mahony, Clancy, M., Dempsey, R., O’Brien, M., \& Jordan, K. (2009). Listeria monocytogenes in the Irish dairy farm environment. Journal of Food Protection, 72(7), 1450-1456. http://dx.doi. org/10.4315/0362-028X-72.7.1450. PMid:19681268.

Gérard, A., El-Hajjaji, S., Niyonzima, E., Daube, G., \& Sindic, M. (2018). Prevalence and survival of Listeria monocytogenes in various types of cheese-A review. International Journal of Dairy Technology, 71(4), 825-843. http://dx.doi.org/10.1111/1471-0307.12552.

Gohar, S., Abbas, G., Sajid, S., Sarfraz, M., Ali, S., Ashraf, M., Aslam, R., \& Yaseen, K. (2017). Prevalence and antimicrobial resistance of Listeria monocytogenes isolated from raw milk and dairy products. Matrix Science Medica, 1(1), 10-14. http://dx.doi.org/10.26480/ msm.01.2017.10.14.

Ibba, M., Cossu, F., Spanu, V., Virdis, S., Spanu, C., Scarano, C., \& De Santis, E. P. L. (2013). Listeria monocytogenes contamination in dairy plants: evaluation of Listeria monocytogenes environmental contamination in two cheese-making plants using sheeps milk. Italian Journal of Food Safety, 2(2), 31. http://dx.doi.org/10.4081/ ijfs.2013.e31.

International Standart Organisation - ISO. (1996). ISO 11290-1 Microbiology of food and animal feeding stuffs-Horizontal method for the detection and enumeration of Listeria monocytogenes - Part 1: Detection method. Geneva: ISO.

Kasalica, A., Vuković, V., Vranješ, A., \& Memiši, N. (2011). Listeria monocytogenes in milk and dairy products. Biotechnology in Animal Husbandry, 27(3), 1067-1082. http://dx.doi.org/10.2298/ BAH1103067K.

Konosonoka, I. H., Jemeljanovs, A., Osmane, B., Ikauniece, D., \& Gulbe, G. (2012). Incidence of Listeria spp. in Dairy Cows Feed and Raw Milk in Latvia. ISRN Veterinary Science, 2012, 1-5. http://dx.doi. org/10.5402/2012/435187. PMid:23738125.

Leong, D., Alvarez-Ordóñez, A., \& Jordan, K. (2014). Monitoring occurrence and persistence of Listeria monocytogenes in foods and food processing environments in the Republic of Ireland. Frontiers in Microbiology, 5, 436. http://dx.doi.org/10.3389/fmicb.2014.00436. PMid:25191314.

Mary, M. S., \& Shrinithivihahshini, N. D. (2017). Pervasiveness of Listeria monocytogenes in Milk and Dairy Products. J Food Microbiol Saf Hyg, 2(125), 2476-2059. http://dx.doi.org/10.4172/2476-2059.1000125.

Muhterem-Uyar, M. M., Dalmasso, M., Bolocan, A. S., Hernandez, M., Kapetanakou, A. E., Kuchta, T., Manios, S. G., Melero, B., Minarovičová, J., Nicolau, A. I., Rovira, J., Skandamis, P. N., Jordan, K., RodríguezLázaro, D., Stessl, B., \& Wagner, M. (2015). Environmental sampling for Listeria monocytogenes control in food processing facilities reveals three contamination scenarios. Food Control, 51, 94-107. http://dx.doi.org/10.1016/j.foodcont.2014.10.042.

Murru, N., Peruzy, M. F., De Carlo, E., Mercogliano, R., Aponte, M., Morena, C., Serluca, G., \& Fraulo, P. (2018). Listeria monocytogenes survival during production and storage of water buffalo Mozzarella cheese. International Journal of Dairy Technology, 71(2), 356-361. http://dx.doi.org/10.1111/1471-0307.12449.

Muthulakshmi, K., Uma, C., Sivagurunathan, P., \& Satheeshkumar, S. (2018). Occurrence of listeria monocytogenes in milk and milk 
products. International Journal of Recent Research in Life Sciences, 7, 1572-1574.

Navratilova, P., Schlegelova, J., Sustackova, A., Napravnikova, E., Lukasova, J., \& Klimova, E. (2004). Prevalence of Listeria monocytogenes in milk, meat and foodstuff of animal origin and the phenotype of antibiotic resistance of isolated strains. Czech Academy of Agricultural Sicences, 49(7), 243-252. http://dx.doi.org/10.17221/5701-VETMED.

Owusu-Kwarteng, J., Wuni, A., Akabanda, F., \& Jespersen, L. (2018). Prevalence and characteristics of listeria monocytogenes isolates in raw milk, heated milk and nunu, a spontaneously fermented milk beverage, in Ghana. Beverages, 4(2), 40. http://dx.doi.org/10.3390/ beverages4020040.

Şanlibaba, P., Uymaz Tezel, B., \& Çakmak, G. A. (2018). Detection of Listeria spp. in raw milk and dairy products retailed in Ankara. Food, 43(2), 273-282. http://dx.doi.org/10.15237/gida.GD17107.

Sarfraz, M., Ashraf, Y., \& Ashraf, S. (2017). A review: prevalence and antimicrobial susceptibility profile of listeria species in milk products. Matrix Science Medica, 1(1), 3-9.
Stahl, V., Garcia, E., Hezard, B., \& Fassel, C. (1996). Prevention of Listeria monocytogenes contamination on dairy farms and in the cheese industry. Pathologie Biologie, 44(9), 816-824. PMid:8977904.

Todar, K. (2009). Listeria monocytogenes. Todar's Online Textbook of Bacteriology. Retrieved from http:// textbookof bacteriology.net/ Listeria.html

Tomar, O., \& Akarca, G. (2018). Microbiological properties of afyon kaymak sold in afyonkarahisar province. European Journal of Science and Technology, 14, 102-109.

Tomar, O., \& Akarca, G. (2019). Critical control points and food pathogen presence in dairy plants from Turkey. Food Science and Technology (Campinas), 39(2), 444-450. http://dx.doi.org/10.1590/fst.29717.

Turkey. (2003, September 27). Turkish Food Codex Regulation, Communique on Cream and Kaymak (no. 25242). Official Journal.

Turkey. (2011, November 29). Regulation on Turkish Food Codex Microbiological Criteria (no. 208157). Official Journal. 